\title{
Knowledge and Attitude Relationship With Prevention Corona Virus Disease (Covid-19)
}

\author{
Susilia Idyawati*, Ni Putu Aryani, Baiq Ricca Afrida, Nurul Hikmah Annisa, Anna \\ Layla Salfarina
}

Midwifery Diploma, Institute of Health Sciences Yarsi Mataram, Mataram, West Nusa Tenggara

* Corresponding author. Email: idyawatisusilia004@gmail.com

\begin{abstract}
Corona Virus Disease or what is often called COVID-19 is a problem in the world and also in Indonesia. Data on positive cases of COVID-19 in West Lombok as of 1 May 2020 were 35 positive cases. According to WHO, COVID-19 is spread from person to person through tiny droplets from the nose or mouth that are spread when a person coughs or exhales. The aim of this study was to determine the knowledge and attitude relationship with prevention Corona Virus Disease (Covid-19). This research method is an analytical observational study.

The population are the house wife count of 626.941 and the sample technique is proportional sampling a number of 364 people. The data was collected with instrument as be a questioner. The data analysis used is the ChiSquare test. The result shows that there was a relationship between knowledge and Covid-19 transmission prevention behavior. The OR value of 27.8 indicates that people with good knowledge have a 27.8 times chance of doing prevention. The relationship between attitudes and behavior to prevent Covid-19 transmission has an OR value of 41.8 , indicating that people who are positive have 41.8 times the chance to take prevention compared to those who are negative. In conclusion, a person's knowledge and attitude about COVID-19 will affect the prevention of transmission of covid-19 in communities in West Lombok.
\end{abstract}

Keywords: knowledge, attitude, covid-19

\section{INTRODUCTION}

Corona Virus Disease or what is often called COVID-19 is a problem in the world and also in Indonesia. The World Health Organization (WHO) has designated COVID-19 as a pandemic and has become the national emergency status for Corona in Indonesia. This virus is an infectious disease and was only discovered in Wuhan, China in December 2019 which later became an epidemic

The latest data related to Corona on May 3, 2020, obtained data on the number of positive cases of COVID-19 in Indonesia, there were 10,843 cases (including those who had recovered). Meanwhile, the top 10 positive cases of COVID-19 in DKI Jakarta were 4,317 cases, East Java 1,034 cases, West Java 1,012 cases, Central Java 746 cases, South Sulawesi 547 cases, Banten 418 cases, Bali 235 cases, West Nusa Tenggara (NTB) 250 cases, Papua 210 cases and South Kalimantan 179 cases [1].

Data on positive cases of COVID-19 in West Lombok as of 1 May 2020 were 35 positive cases with details of 6 recovering and 29 still positive. The highest number of positive cases came from Batu Layar District and no cases in Sheet District. The number of PDP is 52 people and the number of ODP is 40 people (West Lombok Health Office, 2020).

Indonesia including West Nusa Tenggara Province which has tested positive for COVID-19 as many as one person. This needs to be done to prevent transmission to other people. Indonesia has taken a number of steps including increasing the emergency response including a declaration of a national emergency status. WHO and Indonesia agreed to increase cooperation in dealing with COVID-19.

According to WHO, COVID-19 is spread from person to person through the tiny droplets from the nose or mouth that are spread when a person coughs or exhales. These droplets then fall on objects that are touched by other people. The person then touches the eyes, nose or mouth. Based on existing studies there has not been found the spread of COVID-19 through free air.

Based on the report of the government spokesperson for handling the Corona virus, Achmad Yurianto, the Corona virus has been observed to have spread to all regions in Indonesia including West Nusa Tenggara Province which has tested positive for COVID-19 as many as one person. This needs to be done to prevent transmission to other people. Indonesia has taken a number of steps including increasing the emergency response including a declaration of a national 
emergency status. WHO and Indonesia agreed to increase cooperation in dealing with COVID-19.

A number of other points that WHO asked Indonesia to do include educating and actively communicating with the public through appropriate communication and public relations channels, intensifying case finding, contact tracing, surveillance, contact quarantine and isolation of cases (positive ones), expanding COVID-19 surveillance. using the existing respiratory disease surveillance system and hospitalbased surveillance, as well as conducting suspect tests based on the WHO definition, both contacts and confirmed patients, testing identified patients through respiratory disease surveillance.

Based on the background description that has been described and the problems that have occurred, that COVID-19 is a problem both in the world and in Indonesia. For this reason, promotional and preventive efforts are needed to increase public awareness about clean and healthy living habits so that COVID-19 does not spread. Efforts to prevent the spread of COVID-19 can be done through early detection, namely through research on the relationship of knowledge and attitudes with the prevention of transmission of Corona Virus Disease (COVID-19).

\section{METHODS}

This research is an analytic observational study. The data collection tools in this study include a questionnaire. The questionnaire includes a section on response characteristics, questions about preventing transmission of COVID-19. The data analysis used was the Chi-Square test.

\section{RESULTS}

The relationship between knowledge and Covid-19 transmission prevention behavior shows that respondents who have good knowledge and have good behavior are 209 people $(87.4 \%)$, while respondents who have poor knowledge and behave less well are 100 people (80.0\%). Further analysis shows that the p-value is 0,000 , which means that there is a relationship between knowledge and behavior to prevent Covid-19 transmission. The OR value of 27.8 shows that people with good knowledge have a 27.8 times chance of doing prevention compared to those with low knowledge.

The relationship between attitude and Covid-19 transmission prevention behavior shows that respondents who have positive attitudes and have good behavior are 216 people $(88.2 \%)$, while respondents who have negative attitudes and behave less well are 101 people (84.9\%). Further analysis shows that the p-value is 0,000 , which means that there is a relationship between attitudes and behavior to prevent Covid-19 transmission. The OR value of 41.8 shows that people who are positive have 41.8 times the chance to take precautions compared to those who are negative.

Table 1. Corelation of Knowledge with Covid-19 Pervention

\begin{tabular}{|c|c|c|c|c|c|}
\hline Knowledge of COVID-19 & \multicolumn{3}{|c|}{ Covid-19 Pervention } & p-value & OR \\
\cline { 2 - 5 } & Good & Less & Total & & \\
\hline Good & 209 & 30 & 239 & 0.000 & 27.8 \\
& $(87.4 \%)$ & $(12.6 \%)$ & $(100.0 \%)$ & & \\
\hline Less & 25 & 100 & 125 & & \\
& $(20.0 \%)$ & $(80.0 \%)$ & $(100.0 \%)$ & & \\
\hline Total & 234 & 130 & 364 & & \\
& $(64.3 \%)$ & $(35.7 \%)$ & $(100.0 \%)$ & & \\
\hline
\end{tabular}

Table 2. Corelation of Attitude with Covid-19 Pervention

\begin{tabular}{|l|c|c|c|c|c|}
\hline \multirow{2}{*}{ Attitude of Covid-19 } & \multicolumn{3}{|c|}{ Covid-19 Pervention } & p-value & OR \\
\cline { 2 - 5 } & Good & Less & Total & & \\
\hline Positive & 216 & 29 & 245 & 0.000 & 41.8 \\
& $(88.2 \%)$ & $(11.8 \%)$ & $(100.0 \%)$ & & \\
\cline { 1 - 4 } Negative & 18 & 101 & 119 & & \\
& $(15.1 \%)$ & $(84.9 \%)$ & $(100.0 \%)$ & & \\
\hline Total & 234 & 130 & 364 & & \\
& $(64.3 \%)$ & $(35.7 \%)$ & $(100.0 \%)$ & & \\
\hline
\end{tabular}




\section{DISCUSSIONS}

\subsubsection{Corelation of Knowledge with Covid-19 Pervention}

The measurement of respondents' knowledge in this study is to explore a person's thinking ability through filling out a questionnaire that asks about material about Covid-19. The measured cognitive aspects include the level of understanding, memorizing, applying, analyzing, synthesizing and the ability to evaluate. The purpose of measuring the cognitive aspect is to explore thinking skills, such as remembering to solving problems.

There is a relationship between knowledge and behavior to prevent Covid-19 transmission. Most of the respondents' knowledge about Covid-19 is in the good category due to various factors. The factors that affect a person's knowledge include the following: a) age, an increasing person can make changes in physical, psychological, and psychological aspects. In the psychological aspect, the level of thinking of a person will be more mature and mature so that it can make the acceptance of knowledge better. Most of the respondents in this study were in the productive category; b) education, the higher the level of education, a person will more easily accept something new and adapt easily to the environment. All respondents in this study were health students, so they had good knowledge about Covid-19; respondents are health students related to exposure to health information; $\mathrm{f}$ ) socio-economic, sharing knowledge among social groups will increase knowledge. Meanwhile, economic conditions or sufficient income will increase one's knowledge, because with sufficient income, it will support all the needs for knowledge, compared to families with less economies. In the family economy, most of the parents' jobs are farmers and fishermen whose needs are fulfilled; g) culture or culture that a person adopts, will affect the level of one's knowledge, because new information will be filtered roughly according to his or her culture. Culture can also influence a person's perception and attitude towards an object or event. The culture in which we were born and raised has a considerable influence on the formation of a person's way of thinking and behavior. The learning culture of the respondents supports the respondents' knowledge in a good category; h) interest or feeling of interest in something or activity, without coercion from others. Interest makes someone to try and pursue something new and in the end more knowledge can be obtained than before; i) exposure to information / media Information exposure can be through electronic or printed media. Someone who is often exposed to the media, especially the information presented by the media, will increase his knowledge. Print media can be in the form of magazines, newspapers and newsletters, while electronic media can be in the form of radio and television. Health students tend to be exposed to health information so that knowledge about Covid-19 is also in a good category.

\subsubsection{Corelation of Attitude with Covid-19 Pervention}

There is a relationship between attitude and behavior to prevent Covid-19 transmission. Most respondents have a positive attitude towards Covid-19 prevention due to various factors. The factors that influence attitude formation include: a) Personal experience; what a person experiences will affect his assessment of an object or event; b) Influence of others; someone has an attitude that is in line with the attitude of people who are considered influential (parents, close friends, peers, teachers, religious leaders); c) Culture; habits carried out in one's environment will affect the formation of a person's attitude; d) Mass media; which gives messages, then influences, gives suggestions, thus forming attitudes; e) Educational / religious institutions; the teachings of good and bad (moral) obtained at educational or religious institutions will shape one's attitude; f) Emotional factors; attitude is sometimes an emotional statement, or a form of ego defense mechanism.

\section{CONCLUSION}

A person's knowledge and attitude about COVID-19 will affect the prevention of transmission of covid-19 in communities in West Lombok.

\section{ACKNOWLEDGMENT}

Thanks to the West Lombok district health office for the research permission given during the pandemic and the community who were willing to become respondents in this study

\section{REFERENCES}

[1] The Ministry of Health Republic of Indonesia, The Reaserch of Basic Health, 2020.

[2] West Lombok Health Office, 2020

[3] Centers for Disease Control and Prevention (2020). 2019 Novel Coronavirus, Wuhan, China.

[4] Citroner, G. Healthline (2020). China Coronavirus Outbreak: CDC Issues Warning, Multiple Cases in U.S.

[5] Dahlan S. (2018). Besar sampel dan cara pengambilan sampel dalam penelitian kedokteran dan kesehatan. Jakarta: Salemba Medika.

[6] Evans, M. Patient (2020). Wuhan Coronavirus: What You Need to Know. WebMD (2020). Coronavirus.

[7] Glanz, Karen., Rime, Barbara K., Viswanath, K. (2008). Health Behavior And Health Education. Theory, Research, and Practice. 4th Edition. San Fransisco: Jossey-Bass. 
[8] Hastono SP. (2014). Analisis data kesehatan. Depok: Fakultas Kesehatan Masyarakat Universitas Indonesia.

[9] Hidayat AA. (2014). Riset keperawatan dan teknik penulisan ilmiah. Jakarta: Salemba Medika.

[10] Huang, et al. (2020). Clinical features of patients infected with 2019 novel Coronavirus in Wuhan, China. The Lancet, 6736(20), pp. 1-10. 